\title{
Effect of Fertilizer Application and Spacing on the Growth and Yield of Taro [Colocasia esculenta (L.) Schott.]
}

\author{
Deepa Bhatt*, Karan Vir Singh, A.K. Barholia and Devendra Vishvkarma \\ Department of Horticulture, Rajimata Vijayaraje Scindia Krishi Vishwa Vidyalaya, College of \\ Agriculture, Gwalior, Madhya Pradesh -474 002, India \\ *Corresponding author
}

\begin{tabular}{|l|}
\hline Ke y w o r d s \\
Fertilizer, \\
$\begin{array}{l}\text { Spacing, } \\
\text { Growth, } \\
\text { Yield, Taro }\end{array}$ \\
\hline Article Info \\
\hline $\begin{array}{l}\text { Accepted: } \\
20 \text { November } 2019 \\
\text { Available Online: } \\
\text { 10 December } 2019\end{array}$ \\
\hline
\end{tabular}

\section{Introduction}

Taro (Colocasia esculenta L. Schott) commonly known as arbi, tarul, dasheen, champadhumpa and eddoe. It is an important staple food crop grown throughout many Pacific island countries, parts of Africa, Asia and the Caribbean and is thought to have originated in North Eastern India and Asia (Kuruvilla and Singh, 1981; Ivancic, 1992) 
and gradually spread worldwide by settlers. It is widely grown as a rainfed crop in the valley and Jhum area in entire North Eastern States of India. Colocasia esculenta is an herbaceous, perennial root crop that has the character of being an underground stem. It is different from yam as it is not a tuber but a corm. Taro leaves are heart shaped which are $5.0-7.6 \mathrm{~cm}$ long and $2.5-5.0 \mathrm{~cm}$ across on $7.6 \mathrm{~cm}$ long petioles that all emanate from an upright tuberous rootstock, called a corm. The petioles are thick and succulent, which attaches near the centre of the leaf. The corm is shaped like a top with rough ridges, lumps and spindly roots, and skin of corm and cormels are brown with white or pink color flesh. Colocasia produces smaller corms or "cormels" which grow off the sides of the main corm.

The crop of colocasia has a triple value in that the stem may be used as salads, the tubers provide easily digested starch, while the leaves are used as a green vegetable. The major economic parts are corm and cormels which have a nutritional value comparable to sweet potato, while the young leaves used for food

contains about $23 \%$ protein on a dry weight basis. It is also rich in calcium, phosphorus, iron, vitamin $\mathrm{C}$, thiamine, riboflavin and niacin, which are important constituents of human diets. Corms and cormels possess a high nutritional value. The corm is a rich source of carbohydrate, the majority being starch. Taro corms and cormels have a high economic value in urban markets.

The taro industry provides valuable employment to a large number of people, mostly in rural areas. There are considerable opportunities for diversification and utilization of taro crop. From a global view, taro will be increasingly used in processed form of food, feed and starch derived products.
Nutrient management and spacing are the major regulating factors to get the maximum yield and quality of any crop. Sensible and suitable use of nutrients and spacing are essential to improve yield and quality of produce. The present experiment was therefore, carried out to find out suitable plant spacing and optimum fertilizer dose for better growth and higher yield of taro.

\section{Materials and Methods}

Field experiments were carried out in the research field of Department of Horticulture, College of Agriculture, RVSKVV, Gwalior during two consecutive kharif seasons of 2017 and 2018 on taro [Colocasia esculenta (L.) Schott.]. Three levels of fertilizer dose i.e. $F_{1}$ = full FYM (10t/ha.) + recommended dose of NPK (80:60:60 kg/ha), $F_{2}=$ full FYM (10t/ha.) $+75 \%$ of recommended dose of NPK $(60: 45: 45 \mathrm{~kg} / \mathrm{ha}), \mathrm{F}_{3}=$ full FYM (10t/ha.) $+125 \%$ of recommended dose of NPK (100:75:75 kg/ha) and three levels of spacing i.e. $S_{1}=(0.60 \mathrm{~m} \times 0.30 \mathrm{~m}), S_{2}=(0.60 \mathrm{~m} \times$ $0.45 \mathrm{~m})$ and $S_{3}=(0.60 \mathrm{~m} \times 0.60 \mathrm{~m})$ were used as treatment variables in the present study. The experiments were conducted in a factorial randomized block design with three replications. The unit plot size was $3.6 \mathrm{~m}$ x 3.6 $\mathrm{m}$. The variety used in the experiment was "Narendra Arbi-1". The crop was fertilized with as per treatment. Intercultural operations were done as and when required. Observations on five plant growth characters viz. height of plant $(\mathrm{cm})$, number of leaves per plant, petiole length $(\mathrm{cm})$, number of petioles per plant and number of side shoots per plant and yield and yield attributes namely number of corms per plant, number of cormels per plant, corm length $(\mathrm{mm})$, cormel length $(\mathrm{mm})$, corm diameter $(\mathrm{mm})$, cormel diameter $(\mathrm{mm})$, Average corm weight (g), Average cormel weight (g), Yield per plant (g) and Yield (t/ha) were recorded. Ten plants were randomly selected from each plot for recording yield 
contributing characters. The growth and yield data was recorded from an area of $12.96 \mathrm{~m}^{2}$ in each plot and per hectare yield was calculated. Corms and cormels were considered to calculate yield data which were mentioned as edible yield. The experimental data recorded were subjected to statistical analysis using analysis of variance technique suggested by Panse and Sukhatme (1967) and presented in Table 1 and 2. The critical differences for the treatments comparison were worked out, wherever the " $F$ " test was found significant at $5 \%$ level of significance.

\section{Results and Discussion}

The results of present investigation showed significant differences for the growth stages (Table 1).

\section{Height of plant}

Different fertilizer level showed significant variations in the plant height of taro. Fertilizer level had significant effect on the height of plant. The maximum plant height $(88.85 \mathrm{~cm}$ and $88.57 \mathrm{~cm}$ ) was noticed in treatment $\mathrm{F}_{3}$ followed by $F_{1}$. While the lowest plant height $(66.71 \mathrm{~cm}$ and $68.23 \mathrm{~cm})$ was recorded in treatment $\mathrm{F}_{2}$, respectively in both the year 2017 and 2018. Plant spacing had significant effect on the height of plant. In 2017, the plant spacing of $S_{3}(0.60 \mathrm{~m} \times 0.60 \mathrm{~m})$ produced the maximum plant height $(80.22 \mathrm{~cm})$ and the minimum plant height $(73.41 \mathrm{~cm})$ was obtained in the plant spacing of $S_{1}(0.60 \mathrm{~m} x$ $0.30 \mathrm{~m})$. While, the plant spacing $\mathrm{S}_{3}$ was statistically at par with the spacing of $S_{2}$ during the year 2017. In 2018, the plant spacing of $S_{3}(0.60 \mathrm{~m} \times 0.60 \mathrm{~m})$ produced the maximum plant height $(82.08 \mathrm{~cm})$. The minimum plant height $(75.12 \mathrm{~cm})$ was obtained in the plant spacing of $S_{1}(0.60 \mathrm{~m} \mathrm{x}$ $0.30 \mathrm{~m})$. While, the plant spacing $S_{1}$ and $S_{3}$ was statistically at par with the spacing of $\mathrm{S}_{2}$ during the year 2018. The result indicated that the plant height increased with the decrease in spacings and the results is agreed upon with Purewall and Daragan (1957).

\section{Number of leaves per plant}

The highest number of leaves per plant $(5.48$ and 5.38) was observed in the treatment $F_{3}$ and the lowest number of leaves per plant (4.18 and 4.16) was recorded in $F_{2}$, respectively in both the year 2017 and 2018 . Plant spacing had significant effect on the number of leaves of taro. The highest number of leaves per plant (5.33 and 5.28) was obtained in $\mathrm{S}_{3}(0.60 \mathrm{~m} \times 0.60 \mathrm{~m})$ spacing and the lowest number of leaves per plant (4.51 and 4.41) was noticed in $S_{1}(0.60 \mathrm{~m} \times 0.30 \mathrm{~m})$, which was statistically similar with the $S_{2}$ $(0.60 \mathrm{~m} \times 0.45 \mathrm{~m})$, respectively in both the year 2017 and 2018.

\section{Petiole length}

The highest petiole length $(86.95 \mathrm{~cm}$ and $87.25 \mathrm{~cm})$ was recorded in the treatment $\mathrm{F}_{3}$. However, the lowest petiole length $(67.52 \mathrm{~cm}$ and $66.35 \mathrm{~cm}$ ) was recorded in $\mathrm{F}_{2}$, respectively in both the year 2017 and 2018. The highest petiole length $(78.07 \mathrm{~cm}$ and $80.37 \mathrm{~cm})$ was obtained in $S_{3}(0.60 \mathrm{~m} \times 0.60 \mathrm{~m})$ spacing and the lowest petiole length was noticed in $S_{1}$ $(0.60 \mathrm{~m} \times 0.30 \mathrm{~m})$. However, plant spacing $\mathrm{S}_{3}$ was statistically at par with $S_{2}$ respectively during both the year 2017 and 2018.

\section{Number of petiole per plant}

The highest number of petiole per plant (5.66 and 6.53) was observed in the treatment $F_{3}$ and the lowest number of petioles per plant (4.25 and 4.39) was recorded in $F_{2}$, respectively in both the year 2017 and 2018. Plant spacing had significant effect on the number of petiole per plant of taro (Table 1). The plant spacing i.e. $S_{3}(0.60 \mathrm{~m} \times 0.60 \mathrm{~m})$ produced the maximum number of petiole per 
plant (5.25 and 5.82) and the minimum number of petiole per plant (4.70 and 4.89) was obtained in the spacing of $S_{1}(0.60 \mathrm{~m} x$ $0.30 \mathrm{~m})$. However, plant spacing of $S_{1}$ were statistically at par with $\mathrm{S}_{2}$, during the year 2017 only. This result was found in agreement with that of Dhar (1989).

\section{Number of side shoots per plant}

In 2017, the minimum number of side shoots per plant (2.51) was recorded in $\mathrm{F}_{2}$ and the maximum number of side shoots per plant (3.01) recorded in $F_{3}$, which was statistically similar with $\mathrm{F}_{1}$. In 2018, the minimum number of side shoots per plant (2.61) was recorded in $\mathrm{F}_{2}$ and the maximum number of side shoots per plant (3.22), recorded in $F_{3}$. The variation in the number of side shoots due to plant spacing was found to be significant. There was a significant increase in the number of side shoots per plant with the increase in plant spacing. In 2017, the plant spacing of $S_{3}$ $(0.60 \mathrm{~m} \times 0.60 \mathrm{~m})$ produced the maximum number of side shoots per plant (2.97), which was at par with $S_{2}(0.60 \mathrm{~m} \times 0.45 \mathrm{~m})$ and the minimum number of side shoots per plant (2.68) was obtained in the plant spacing of $S_{1}$ $(0.60 \mathrm{~m} \times 0.30 \mathrm{~m})$. In 2018 , the plant spacing of $\mathrm{S}_{3}(0.60 \mathrm{~m} \times 0.60 \mathrm{~m})$ produced the maximum number of side shoots per plant (3.12) and the minimum number of side shoots per plant (2.81) was obtained in the plant spacing of $S_{1}$ $(0.60 \mathrm{~m} \times 0.30 \mathrm{~m})$ which was statistically at par with $\mathrm{S}_{2}(0.60 \mathrm{~m} \times 0.45 \mathrm{~m})$.

\section{Number of corms per plant}

The highest number of corms per plant $(2.08$ and 1.98) was observed in the treatment $\mathrm{F}_{3}$ followed by treatment of $F_{1}$. However, the lowest number of corms per plant (1.40 and 1.29) was recorded in $F_{2}$, respectively in both the year 2017 and 2018. The variation in the number of corms due to plant spacing was found to be significant (Table 2). The plant spacing of $S_{1}(0.60 \mathrm{~m} \times 0.30 \mathrm{~m})$ produced the minimum number of corms per plant (1.59 and 1.49 ) and the maximum number of corms per plant (1.89 and 1.76) was obtained in the plant spacing of $\mathrm{S}_{3}(0.60 \mathrm{~m} \times 0.60 \mathrm{~m})$, which was at par with plant spacing of $S_{2}(0.60 \mathrm{~m} \times 0.45 \mathrm{~m})$, respectively in both the year 2017 and 2018.

\section{Number of cormel per plant}

In 2017, the minimum number of cormels per plant (9.45) was recorded in $\mathrm{F}_{2}$, which were at par with treatment $F_{1}$ (9.97) and the maximum number of cormels per plant (11.55) was recorded in $\mathrm{F}_{3}$. In 2018, the minimum number of cormels per plant (9.73) was recorded in $\mathrm{F}_{2}$, which statistically similar with treatment $F_{1}$ (10.39) and the maximum number of cormels per plant (12.01) was recorded in $F_{3}$. The variation in the number of cormels per plant due to plant spacing was found to be significant (Table 2). In 2017, the minimum number of cormels per plant (9.69) was observed in the plant spacing of $S_{1}(0.60 \mathrm{~m} \mathrm{x}$ $0.30 \mathrm{~m}$ ) and the maximum number of cormels per plant (10.92) was obtained in the plant spacing of $\mathrm{S}_{3}(0.60 \mathrm{~m} \times 0.60 \mathrm{~m})$ which was significantly higher than rest of the all other treatments. While, the plant spacing $S_{1}$ and $S_{3}$ was statistically at par with plant spacing of $S_{2}$ $(0.60 \mathrm{~m} \times 0.45 \mathrm{~m})$ made for each other. In 2018, the plant spacing of $S_{1}(0.60 \mathrm{~m} \times 0.30 \mathrm{~m})$ produced the minimum number of cormels per plant (10.19) and the maximum number of cormels per plant (11.27) was obtained in the plant spacing of $S_{3}(0.60 \mathrm{~m} \times 0.60 \mathrm{~m})$. While, the plant spacing $S_{1}$ and $S_{3}$ was statistically at par with plant spacing of $S_{2}(0.60 \mathrm{~m} \times 0.45 \mathrm{~m})$ made for each other during the year 2018. The increase in number of cormel per plant with decrease of plant spacing was also reported by Mannan et al., (1988) and Dhar (1989).

\section{Corm length}

In 2017, the lowest corm length $(47.93 \mathrm{~mm})$ was recorded in $\mathrm{F}_{2}$ which was significantly inferior to rest of the treatments, and the 
highest corm length $(57.16 \mathrm{~mm})$ was recorded in $F_{3}$, which was statistically similar with the $\mathrm{F}_{1}(56.98 \mathrm{~mm})$. In 2018, the minimum corm length $(45.45 \mathrm{~mm})$ was observed in $F_{2}$, followed by $\mathrm{F}_{1}$ and the maximum corm length $(59.06 \mathrm{~mm})$ was noticed in $\mathrm{F}_{3}$. The variation in the corm length due to plant spacing was found to be significant. The plant spacing of $\mathrm{S}_{1}(0.60 \mathrm{~m} \times 0.30 \mathrm{~m})$ produced the lowest corm length $(51.29 \mathrm{~mm} \times 49.59 \mathrm{~mm})$ and the highest corm length $(55.90 \mathrm{~mm} \times 56.00 \mathrm{~mm})$ was obtained in the plant spacing of $\mathrm{S}_{3}(0.60 \mathrm{~m} \times$ $0.60 \mathrm{~m})$ which was statistically similar with plant spacing of $S_{2}(54.87 \mathrm{~mm}$ and $53.58 \mathrm{~mm})$.

\section{Cormel length}

The highest cormel length $(50.19 \mathrm{~mm}$ and
$50.34 \mathrm{~mm}$ ) was observed in the treatment $\mathrm{F}_{3}$ followed by treatment $F_{1}$. However, the lowest cormel length $(34.13 \mathrm{~mm}$ and 34.40 $\mathrm{mm}$ ) was recorded in $\mathrm{F}_{2}$, respectively in both the year 2017 and 2018. The variation in the cormel length due to plant spacing was found to be significant. In 2017, the lowest cormel length $(40.09 \mathrm{~mm})$ was obtained in plant spacing of $S_{1}(0.60 \mathrm{~m} \times 0.30 \mathrm{~m})$ and the highest cormel length $(44.92 \mathrm{~mm})$ was obtained in the plant spacing of $\mathrm{S}_{3}(0.60 \mathrm{~m} \times 0.60 \mathrm{~m})$ which was at par with spacing of $S_{2}(42.62 \mathrm{~mm})$. In 2018 , the plant spacing of $S_{1}(0.60 \mathrm{~m} \times 0.30 \mathrm{~m})$ produced the minimum cormel length $(39.73$ $\mathrm{mm})$ and the maximum cormel length (46.70 $\mathrm{mm})$ was obtained in the plant spacing of $\mathrm{S}_{3}$ $(0.60 \mathrm{~m} \times 0.60 \mathrm{~m})$.

Table.1 Effect of spacing and fertilizer on growth characters of taro in kharif 2017 and 2018

\begin{tabular}{|c|c|c|c|c|c|c|c|c|c|c|}
\hline \multirow[t]{2}{*}{ Treatments } & \multicolumn{2}{|c|}{$\begin{array}{l}\text { Plant height } \\
\text { (cm) }\end{array}$} & \multicolumn{2}{|c|}{$\begin{array}{c}\text { No. of } \\
\text { leaves/plant }\end{array}$} & \multicolumn{2}{|c|}{$\begin{array}{l}\text { Petiole length } \\
\text { (cm) }\end{array}$} & \multicolumn{2}{|c|}{$\begin{array}{c}\text { No. of } \\
\text { petioles/plant }\end{array}$} & \multicolumn{2}{|c|}{$\begin{array}{l}\text { No. of side } \\
\text { shoots/plant }\end{array}$} \\
\hline & 2017 & 2018 & 2017 & 2018 & 2017 & 2018 & 2017 & 2018 & 2017 & 2018 \\
\hline \multicolumn{11}{|c|}{ Fertilizer levels } \\
\hline F1 & 75.95 & 78.96 & 5.06 & 4.91 & 73.93 & 77.22 & 4.96 & 5.32 & 2.96 & 3.05 \\
\hline $\mathbf{F} 2$ & 66.71 & 68.23 & 4.18 & 4.16 & 67.52 & 66.35 & 4.25 & 4.39 & 2.51 & 2.61 \\
\hline F3 & 88.85 & 88.57 & 5.48 & 5.38 & 86.95 & 87.25 & 5.66 & 6.53 & 3.01 & 3.22 \\
\hline S.E.(m) & 1.392 & 1.513 & 0.147 & 0.155 & 2.052 & 1.283 & 0.143 & 0.148 & 0.047 & 0.050 \\
\hline C.D. (at 5\%) & 4.174 & 4.537 & 0.442 & 0.464 & 6.152 & 3.846 & 0.429 & 0.445 & 0.141 & 0.150 \\
\hline \multicolumn{11}{|l|}{ Plant spacing } \\
\hline S1 & 73.41 & 75.12 & 4.51 & 4.41 & 71.38 & 73.50 & 4.70 & 4.89 & 2.68 & 2.81 \\
\hline $\mathbf{S 2}$ & 77.87 & 78.57 & 4.88 & 4.76 & 78.95 & 76.95 & 4.92 & 5.53 & 2.83 & 2.94 \\
\hline S3 & 80.22 & 82.08 & 5.33 & 5.28 & 78.07 & 80.37 & 5.25 & 5.82 & 2.97 & 3.12 \\
\hline S.E.(m) & 1.392 & 1.513 & 0.147 & 0.155 & 2.052 & 1.283 & 0.143 & 0.148 & 0.047 & 0.050 \\
\hline C.D. (at 5\%) & 4.174 & 4.537 & 0.442 & 0.464 & 6.152 & 3.846 & 0.429 & 0.445 & 0.141 & 0.150 \\
\hline
\end{tabular}


Table.2 Effect of spacing and fertilizer on yield contributing characters of taro in kharif 2017 and 2018

\begin{tabular}{|c|c|c|c|c|c|c|c|c|c|c|c|c|c|c|c|c|c|c|c|c|}
\hline \multirow[t]{2}{*}{ Treatments } & \multicolumn{2}{|c|}{$\begin{array}{c}\text { No. of } \\
\text { corms/plant }\end{array}$} & \multicolumn{2}{|c|}{$\begin{array}{c}\text { No. of cormel / } \\
\text { plant }\end{array}$} & \multicolumn{2}{|c|}{$\begin{array}{l}\text { Corm length } \\
\quad(\mathrm{mm})\end{array}$} & \multicolumn{2}{|c|}{$\begin{array}{c}\text { Cormel length } \\
(\mathbf{m m})\end{array}$} & \multicolumn{2}{|c|}{$\begin{array}{l}\text { Corm } \\
\text { diameter } \\
(\mathbf{m m})\end{array}$} & \multicolumn{2}{|c|}{$\begin{array}{c}\text { Cormel } \\
\text { diameter } \\
(\mathbf{m m})\end{array}$} & \multicolumn{2}{|c|}{$\begin{array}{l}\text { Avg. corm } \\
\text { weight (g) }\end{array}$} & \multicolumn{2}{|c|}{$\begin{array}{l}\text { Avg. cormel } \\
\text { weight (g) }\end{array}$} & \multicolumn{2}{|c|}{$\begin{array}{c}\text { Yield/ plant } \\
\text { (g) }\end{array}$} & \multicolumn{2}{|c|}{ Yield (t/ha) } \\
\hline & 2017 & 2018 & 2017 & 2018 & 2017 & 2018 & 2017 & 2018 & 2017 & 2018 & 2017 & 2018 & 2017 & 2018 & 2017 & 2018 & 2017 & 2018 & 2017 & 2018 \\
\hline \multicolumn{21}{|c|}{ Fertilizer levels } \\
\hline $\mathbf{F 1}$ & 1.73 & 1.62 & 9.97 & 10.39 & 56.98 & 54.67 & 43.32 & 43.91 & 46.33 & 44.15 & 21.51 & 20.63 & 49.70 & 50.40 & 12.76 & 13.29 & 165.98 & 165.75 & 6.56 & 6.61 \\
\hline F2 & 1.40 & 1.29 & 9.45 & 9.73 & 47.93 & 45.45 & 34.13 & 34.40 & 35.20 & 35.36 & 18.43 & 19.05 & 44.41 & 45.76 & 10.08 & 10.53 & 140.32 & 141.10 & 5.56 & 5.49 \\
\hline F3 & 2.08 & 1.98 & 11.55 & 12.01 & 57.16 & 59.06 & 50.19 & 50.34 & 50.27 & 49.58 & 26.26 & 24.77 & 53.24 & 53.27 & 14.62 & 15.16 & 201.34 & 199.79 & 7.98 & 7.92 \\
\hline S.E.(m) & 0.056 & 0.051 & 0.225 & 0.254 & 0.925 & 1.367 & 0.784 & 0.827 & 0.747 & 0.794 & 0.438 & 0.480 & 0.860 & 0.876 & 0.274 & 0.284 & 2.839 & 3.415 & 0.112 & 0.156 \\
\hline C.D. (at 5\%) & 0.168 & 0.154 & 0.674 & 0.761 & 2.772 & 4.098 & 2.349 & 2.479 & 2.239 & 2.380 & 1.314 & 1.439 & 2.577 & 2.626 & 0.823 & 0.850 & 8.511 & 10.239 & 0.336 & 0.468 \\
\hline \multicolumn{21}{|l|}{ Plant spacing } \\
\hline S1 & 1.59 & 1.49 & 9.69 & 10.19 & 51.29 & 49.59 & 40.09 & 39.73 & 42.20 & 40.63 & 20.17 & 19.84 & 46.65 & 47.86 & 11.71 & 12.08 & 164.23 & 160.56 & 9.06 & 8.94 \\
\hline $\mathbf{S 2}$ & 1.73 & 1.62 & 10.36 & 10.67 & 54.87 & 53.58 & 42.62 & 42.22 & 43.83 & 42.91 & 22.26 & 21.35 & 49.68 & 50.16 & 12.08 & 12.99 & 167.44 & 171.09 & 6.17 & 6.30 \\
\hline S3 & 1.89 & 1.76 & 10.92 & 11.27 & 55.90 & 56.00 & 44.92 & 46.70 & 45.77 & 45.55 & 23.77 & 23.26 & 51.02 & 51.41 & 13.67 & 13.91 & 175.97 & 174.99 & 4.87 & 4.78 \\
\hline S.E.(m) & 0.056 & 0.051 & 0.225 & 0.254 & 0.925 & 1.367 & 0.784 & 0.827 & 0.747 & 0.794 & 0.438 & 0.480 & 0.860 & 0.876 & 0.274 & 0.284 & 2.839 & 3.415 & 0.112 & 0.156 \\
\hline C.D. (at 5\%) & 0.168 & 0.154 & 0.674 & 0.761 & 2.772 & 4.098 & 2.349 & 2.479 & 2.239 & 2.380 & 1.314 & 1.439 & 2.577 & 2.626 & 0.823 & 0.850 & 8.511 & 10.239 & 0.336 & 0.468 \\
\hline
\end{tabular}

$\mathrm{F}_{1}=$ full FYM (10 t/ha)+ recommended dose of NPK (80:60:60 kg/ha), $F_{2}=$ full FYM (10 t/ha) $+75 \%$ of recommended dose of NPK $(60: 45: 45 \mathrm{~kg} / \mathrm{ha}), \mathrm{F}_{3}=\mathrm{Full}$ FYM (10 t/ha)+125\% of recommended dose of NPK $(100: 75: 75 \mathrm{~kg} / \mathrm{ha}), \mathrm{S}_{1}=(0.60 \mathrm{~m} \times 0.30 \mathrm{~m}), \mathrm{S}_{2}=(0.60 \mathrm{~m} \times 0.45 \mathrm{~m}), \mathrm{S}_{1}=(0.60 \mathrm{~m} \times 0.60 \mathrm{~m})$ 


\section{Corm diameter}

Minimum corm diameter $(35.20 \mathrm{~mm}$ and $35.36 \mathrm{~mm}$ ) was recorded in $F_{2}$ followed by $F_{1}$ and the maximum corm diameter $(50.27 \mathrm{~mm}$ and $49.58 \mathrm{~mm}$ ) recorded in $\mathrm{F}_{3}$, respectively in both the year of 2017 and 2018. The variation in the cormel diameter due to plant spacing was found to be significant. In 2017, the plant spacing of $S_{1}(0.60 \mathrm{~m} \times 0.30 \mathrm{~m})$ produced the minimum corm diameter $(42.20 \mathrm{~mm})$ and the maximum corm diameter $(45.77 \mathrm{~mm})$ was obtained in the plant spacing of $S_{3}(0.60 \mathrm{~m} \mathrm{x}$ $0.60 \mathrm{~m})$. While, the plant spacing $S_{1}$ and $S_{3}$ was statistically at par with plant spacing of $\mathrm{S}_{2}(0.60 \mathrm{~m} \times 0.45 \mathrm{~m})$ made for each other. In 2018 , the plant spacing of $S_{1}(0.60 \mathrm{~m} \times 0.30 \mathrm{~m})$ produced the minimum corm diameter (40.63 $\mathrm{mm}$ ), which was statistically similar with plant spacing of $S_{2}(0.60 \mathrm{~m} \times 0.45 \mathrm{~m})$ and the maximum corm diameter $(45.55 \mathrm{~mm})$ was obtained in the plant spacing of $S_{3}(0.60 \mathrm{~m} \mathrm{x}$ $0.60 \mathrm{~m})$.

\section{Cormel diameter}

Minimum cormel diameter $(18.43 \mathrm{~mm}$ and $19.05 \mathrm{~mm}$ ) was recorded from $\mathrm{F}_{2}$ followed by $\mathrm{F}_{1}$ and the maximum cormel diameter (26.26 $\mathrm{mm}$ and $24.77 \mathrm{~mm}$ ) was recorded in $\mathrm{F}_{3}$, respectively in both the year 2017 and 2018 . The variation in the cormel diameter due to plant spacing was found to be significant. The plant spacing of $S_{1}(0.60 \mathrm{~m} \times 0.30 \mathrm{~m})$ produced the minimum cormel diameter $(20.17 \mathrm{~mm}$ and $19.84 \mathrm{~mm}$ ) and the maximum cormel diameter $(23.77 \mathrm{~mm}$ and $23.26 \mathrm{~mm})$ was obtained in the plant spacing of $S_{3}(0.60 \mathrm{~m} \mathrm{x}$ $0.60 \mathrm{~m}$ ), respectively in both the year 2017 and 2018.

\section{Average corm weight (g)}

The highest average corm weight $(53.24 \mathrm{~g}$ and $53.27 \mathrm{~g}$ ) was recorded in the treatment $\mathrm{F}_{3}$. However, the lowest average corm weight (44.41 $\mathrm{g}$ and $45.76 \mathrm{~g})$ was recorded in treatment $\mathrm{F}_{2}$, respectively in both the year 2017 and 2018. The average weight of corms was recorded at harvest. A significant variation in the average weight of corms due to plant spacing was observed (Table 2). In 2017, the minimum average corm weight $(46.65 \mathrm{~mm})$ was observed in the plant spacing of $S_{1}(0.60 \mathrm{~m} \times 0.30 \mathrm{~m})$ and the maximum average corm weight $(51.02 \mathrm{~mm})$ was obtained in the plant spacing of $S_{3}(0.60 \mathrm{~m} \mathrm{x}$ $0.60 \mathrm{~m})$ which was identical with spacing of $\mathrm{S}_{2}(0.60 \mathrm{~m} \times 0.45 \mathrm{~m})$. In 2018 , the plant spacing of $S_{1}(0.60 \mathrm{~m} \times 0.30 \mathrm{~m})$ produced the minimum average corm weight $(47.86 \mathrm{~mm})$ and the maximum average corm weight $(51.41 \mathrm{~mm})$ was obtained in the plant spacing of $S_{3}(0.60 \mathrm{~m} \times 0.60 \mathrm{~m})$ which was at par with $\mathrm{S}_{2}(0.60 \mathrm{~m} \times 0.45 \mathrm{~m})$ made for each other. All the treatments of various spacings were significantly superior with each other during $2017 \& 2018$. As incase of number of corms per plant the plant spacing of $0.60 \mathrm{~m} \times 0.30 \mathrm{~m}$ resulted in the highest average weight of corms and the lowest from the closest one. However, there was a trend of decrease in the average weight of corms with the increase in plant spacing. The increase in corm average weight with decrease spacing was also reported by Dhar (1989).

\section{Average cormel weight (g)}

The highest average cormel weight (14.62 $\mathrm{g}$ and $15.16 \mathrm{~g}$ ) was recorded in the treatment $\mathrm{F}_{3}$ followed by $F_{1}$. However, the lowest average cormel weight (10.08 $\mathrm{g}$ and $10.53 \mathrm{~g})$ was recorded in treatment $F_{2}$, respectively in both the year 2017 and 2018. The average weight of cormel was recorded at harvest. A significant variation in the average weight of cormel due to plant spacing was observed (Table 2). In 2017, the minimum average cormel weight $(11.71 \mathrm{~mm})$ was observed in the plant spacing of $S_{1}(0.60 \mathrm{~m} \times 0.30 \mathrm{~m})$ and it was at par with spacing of $S_{2}(0.60 \mathrm{~m} \times 0.45 \mathrm{~m})$ and the maximum average cormel weight $(13.67 \mathrm{~mm})$ was obtained in the plant spacing 
of $S_{3}(0.60 \mathrm{~m} \times 0.60 \mathrm{~m})$. In 2018 , the plant spacing of $S_{1}(0.60 \mathrm{~m} \times 0.30 \mathrm{~m})$ produced the minimum average cormel weight $(12.08 \mathrm{~mm})$ and the maximum average cormel weight $(13.91 \mathrm{~mm})$ was obtained in the plant spacing of $S_{3}(0.60 \mathrm{~m} \times 0.60 \mathrm{~m})$ followed by $\mathrm{S}_{2}(0.60 \mathrm{~m}$ $\mathrm{x} 0.45 \mathrm{~m})$.

\section{Yield per plant (g)}

The economic yield per plant $(201.34 \mathrm{~g}$ and $199.79 \mathrm{~g}$ ) was highest in treatment $F_{3}$ followed by $F_{1}$ i.e., $165.98 \mathrm{~g}$ and $165.75 \mathrm{~g}$. The lowest yield $(140.32 \mathrm{~g}$ and $141.10 \mathrm{~g})$ were recorded in the treatment $F_{2}$, respectively in both the year 2017 and 2018. In 2017, the minimum yield per plant $(164.23 \mathrm{~g})$ was recorded in the plant spacing of $S_{1}(0.60 \mathrm{~m} \times 0.30 \mathrm{~m})$ which was statistically at par with plant spacing of $\mathrm{S}_{2}$ $(0.60 \mathrm{~m} \times 0.45 \mathrm{~m})$ and the maximum yield per plant $(175.97 \mathrm{~g})$ was obtained in the plant spacing of $S_{3}(0.60 \mathrm{~m} \times 0.60 \mathrm{~m})$. In 2018 , the plant spacing of $S_{1}(0.60 \mathrm{~m} \times 0.30 \mathrm{~m})$ produced the minimum yield per plant (160.56 g) and the maximum yield per plant (174.99 g) was obtained in the plant spacing of $S_{3}(0.60 \mathrm{~m} \mathrm{x}$ $0.60 \mathrm{~m}$ ) which was statistically at par with plant spacing of $S_{2}(171.09 \mathrm{~g})$.

\section{Yield (t/ha)}

The economic yield (7.98 t/ha and $7.92 \mathrm{t} / \mathrm{ha})$ was highest in treatment $F_{3}$ followed by $F_{2}$ i.e., $6.56 \mathrm{t} / \mathrm{ha}$ and $6.61 \mathrm{t} / \mathrm{ha}$. The lowest yield $(5.56 \mathrm{t} / \mathrm{ha}$ and $5.49 \mathrm{t} / \mathrm{ha})$ were recorded in the treatment $F_{2}$, respectively in both the year 2017 and 2018. The plant spacing resulted in significant variation in the yield per hectare. The highest yield $(9.06 \mathrm{t} / \mathrm{ha}$ and $8.94 \mathrm{t} / \mathrm{ha})$ was obtained from the spacing of $S_{1}(0.60 \mathrm{~m} \mathrm{x}$ $0.30 \mathrm{~m})$ and the lowest yield $(4.87 \mathrm{t} / \mathrm{ha}$ and $4.78 \mathrm{t} / \mathrm{ha})$ in the plant spacing of $\mathrm{S}_{3}(0.60 \mathrm{~m} \mathrm{x}$ $0.60 \mathrm{~m}$ ) respectively both in the year 2017 and 2018. This finding is in agreement with the results of Mannan et al., (1988), Basak et al., (1999), and Akther et al., (2016).
The results of the experiment led to the conclusion that the further study might be suggested to use the full FYM (10 t/ha) + 125\% recommended dose of NPK (100:75:75 $\mathrm{kg} / \mathrm{ha})$ and plant spacing $\mathrm{S}_{1}(0.60 \mathrm{~m} \times 0.30 \mathrm{~m})$ for growth and yield of taro.

\section{References}

Akther, S., Ahmed, F, Islam, M.R., Hossen, M.A, and Rahman Talukder, A.H.M.M. (2016). Effect of spacing and fertilizer management on the yield and yield attributes of Mukhikachu (Calocasia esculenta Schott.). Bangladesh J. Agril. Res., 41(4): 713-723.

Basak, N.C., Khan M.A.R., and Sarker, A.H. (1999). Effects of spacings and fertilizers on the agro-economic performance of Panikachu. Bangladesh J. Train. Dev., 12(1\&2): 155-160.

Dhar, M. (1989). Effect of plant spacing and system of planting on the growth and yield of Mukhi Kachu (Calocasia esculenta). M.Sc. (Ag.) Thesis, Dept. Hort. Bangladesh Agric. Univ., Mymensingh, pp. 65-72.

Ivancic, A. (1992). Breeding and genetics of taro (Colocasia esculenta L.) Schott. Ministry of Agriculture and Lands, Solomon Islands UNDP. Food and Agriculture Organizations of the United Nations, pp 1-97.

Kuruvilla, K.M. and Singh, A. (1981). Karyotypic and electrophoretic studies on taro and its origin. Euphytica, 30: 405-413.

Mannan, M.A., Sarkar, A.K. and Rashid, M.M. (1988). Effect of spacing in single and double row systems on the yield and profitability of Mukhi Kachu. Bangladesh J. Agric. Res., 13(2): 89-96.

Panse, V.G. and Sukhatme, B.V. (1967). Statistical Methods for Agricultural Workers. ICAR publication, New Delhi. pp. 100-161. 
Purewall, S.S. and Daragan, K.S. (1957). Effect of spacing on the development and yield of arum (Calocasia esculenta). Indian J. Agric. Sci., 27(2): 151-162.

\section{How to cite this article:}

Deepa Bhatt, Karan Vir Singh, A.K. Barholia and Devendra Vishvkarma. 2019. Effect of Fertilizer Application and Spacing on the Growth and Yield of Taro [Colocasia esculenta (L.) Schott.]. Int.J.Curr.Microbiol.App.Sci. 8(12): 2857-2865.

doi: https://doi.org/10.20546/ijcmas.2019.812.333 